\title{
Using DEA to evaluate efficiency of higher education
}

\author{
Réka Tóth \\ Faculty of Applied Economics and Rural Development \\ University of Debrecen Centre for Agricultural Sciences and Engineering
}

\begin{abstract}
The aim of the higher education reform process both in Hungary and in the European countries is establishing a competitive, qualitative higher education with efficiently operating institutions. The question of efficiency needs increased attention not only because of the decline of the state support but also the rapid raise of the student mass.

In the education system it's not easy to measure the output of the services. The situation is more complicated if an organisation or a sector has multiple inputs and outputs. In this case a possible method of determining efficiency is Data Envelopment Analysis. In my paper I'd like to introduce this method and use it to compare the efficiency of higher education systems. Furthermore I am examining whether their efficiency is influenced by the extent of the contribution of the state and the private sector or socio-economic factors like GDP per capita and education level of parents.
\end{abstract}

Key words: higher education, production efficiency, data envelopment analysis, Tobit regression, sensitivity

\section{Introduction}

\subsection{Efficiency considerations in the financing of higher education}

The viewpoints applied by the different education researchers and analysts for the assessment of the financing systems differ or can differ slightly, their common feature is that they all contain efficiency and equity criteria. Market regulation, quality development and other issues to be studied can be interpreted as parts of the former viewpoints or separately from them.

Most of the analysts differentiate external and external efficiency in the field of education. Kováts (2006) defines three different types of efficiency: allocative, production and dynamic efficiency. Allocative or economic efficiency is the best possible utilization or distribution of the available limited resources for maximizing usefulness (consumer welfare). Production or cost efficiency defines the requirement that the ratio of the production factors should be optimal so that a maximum output could be achieved with the given inputs. Dynamic efficiency refers to the prospective efficiency and determines innovation, the renewal and adaptation ability of the organizations (GVH, 2007). In the present paper, I study the production efficiency of the European higher education systems and relate it to certain elements of the financing mechanism and socio-economic factors.

\subsection{Justification of the role of state and private sector in higher education}

Observing the higher education institutions as a whole, the ratio of public funds used exceeds $70 \%$, in extreme cases - mainly in Scandinavia - it can reach even 97-98\%. It is a fair question why the state finances universities and colleges to such a high extent that is why the state should have a role in higher education. Numerous Hungarian and foreign studies have studied this problem the bases of which were the views of M. Friedman and A. O. Hirschman.

Until the end of the 1980s (the middle of the 1990s) when higher education was free almost everywhere - the analyses emphasised that higher education have a certain public usefulness for society: the average educational and cultural levels and the amount and quality of human resources are improved resulting in higher living standards. These effects of higher education are called environmental effects or externalities in technical terms. Among others, this is what justifies the necessity of state support and the use of public funds (Friedman, 1996).

In addition, there are rational reasons for the state contribution of higher education: one is the imperfection of the capital market. Friedman (1996) explains that the banks and financial institutes do not give enough loans for investing into "people", because it is less safe compared to investment into physical capital. Fixed loans have high risks also for the state. Last but not least, the imperfection of information should also be mentioned as an argument for state support.

The above thoughts of Friedman (1996) can be considered as a part of the human capital theory which might be the most important approach to the economic role of human resources; this theory is of major importance for the subject of the present study. It has been defined by T. W. Schultz. Schultz (1983) claims that although it is against our basic values and beliefs to consider human beings as capital goods, this kind of thinking can answer numerous economic questions and problems. Investment into human capital is important because the acquired knowledge is a decisive factor in economic progress and also because it is a good investment for the individual. One or the major beneficiaries 
of higher education are the individuals, therefore, they have to make a direct contribution to the costs of their own education.

\section{Materials and methods}

While allocative efficiency can be interpreted at the level of society, production efficiency refers to the operation of a company or organization. Organizations - including higher education institutions - can increase their production efficiency either by increasing their output at a constant input or by obtaining the same output with reduced inputs. For determining production efficiency it is usually applied the well-known formula: Efficiency = output / input.

In my study, I apply one input and two output variables for comparing the European higher education systems. The OECD publication, Education at a Glance containing detailed and comprehensive statistics was used as a data source. The input variable is the ratio of expenditure spent on higher education institutes to GDP, the output variables are the ratio of people with a diploma to the total population and their employment rate. For the first output variable, the OECD provides the data according to age groups (the differentiate 4 age groups). As my study focuses on the short term effects of education, the age group of 25 and 34 years was selected, the data represent the ratio of those with a diploma within the population aged between 25 and 34 years. The variables of DEA model are demonstrated in table 1 , the values refer to the year 2006 .

If I used the above formula for calculating efficiency scores, I could compare the value of the input variable to only one of the output variables. However, the countries do not only aim for highly qualified professionals, but they also want that these people could find employment. Therefore, such an efficiency index is needed which can handle if there are multiple input and output variables at an organization. For solving this problem, two major trends were formed: stochastic (based on probability) analysis and the so-called Data Envelopment Analysis (DEA) requiring mathematical programming. For calculating the efficiency index, I used the DEA method which I would like to describe briefly.

The DEA method was worked out by Farrel, Debreu and Koopmann, then it was further developed by Charnes, Cooper and Rhodes at the end of the 1970s. Its basic objective was to determine which units of the organizations (DMUs: decision making units) having several input and output variables operate less efficiently. Since if only one input variable and one output variable are taken into consideration, then only partial efficiency indices can be calculated which can be misleading. Later, a demand arose that the method should provide information how the input units could be changed in order to improve performance. (Cooper et al., 2007) DEA - similarly to production efficiency - can be interpreted with both input-oriented or output-oriented approaches. The outputoriented approach focuses on how high maximal output can be achieved with the same amount of resources. Tibenszkyné (2007) states that the output-oriented approach is the appropriate one for higher education because the principle of cost minimization is not applied according to the market conditions. It should also be taken into consideration that the integration of resources is not always the same in the education process. If they would be utilized at the same level, then we should calculate with constant Return to Scale (CRS), accordingly, variable return to scale (VRS) is preferable. The output-oriented VRS indices of DEA can be obtained by solving the following linear programming equations:

$$
\begin{aligned}
& \max \Phi_{k}+\varepsilon \sum_{r=1}^{s} s_{r}+\varepsilon \sum_{i=1}^{m} s_{i}, \text { supposing that } \\
& \Phi_{k} y_{r k}-\sum_{j=1}^{n} y_{r j} \lambda j+s_{r}=0 \quad \mathrm{r}=1 \ldots \mathrm{s} \\
& x_{i k}-\sum_{r=1}^{n} x_{i j} \lambda j-s_{i}=0, \quad \mathrm{i}=1 \ldots \mathrm{m} \\
& \sum_{j=1}^{n} \lambda_{j}=1, \quad \lambda j, s_{r}, s_{i} \geq 0, \mathrm{j}=1 \ldots \mathrm{n}
\end{aligned}
$$

Source: OECD (2008), WRI (2006) 
In this system of equations s means the number of inputs, $m$ the number of outputs. $y_{r k}$ is the sum of the r outputs of the $k$. production unit, $x_{i k}$ is the sum of its $i$ inputs. $S_{r}$ and $s_{i}$ stands for the weights of the outputs and inputs. The k. unit is considered efficient, if its efficiency score, $\ddot{O}_{k}$ is equal to 1.

The standard DEA model incorporate only discretionary inputs, those whose quantities can be changed at the DMU will, and don't take into account the presence of environmental factors - as non-discretionary inputs. These socio-economic differences can play an important role in determining heterogeneity accross DMUs. The most relevant variables can influence educational outcomes are household wealth, parental education and state support of higher education. Household wealth is measures by GDP per capita refers to 2006. Parental educational attainment means the percentage of population aged 45-54 that has attained at least upper secondary education in 2006. State support is given by the percentage of state contribution to the expenditures of higher education institutions in 2005. (The values of the variables are presented in table 1.) In my paper I'd like to measure the effect of these factors to the efficiency of European higher education systems using a two-staged model.

If $\mathrm{z}_{\mathrm{k}}$ is a non-discretionary input, the following regression is estimated:

$$
\Phi_{k}=z_{, k} \beta+\mathcal{E}_{k}
$$

The efficiency scores are resulted by solving the equations above in the first stage. $\hat{A}$ is the parameter of the nondiscretionary input to be estimated in step two. Since $\Phi_{\mathrm{k}}$ is not a measured, but a calculated bounded variable $\left(\Phi_{\mathrm{k}} \leq 1\right)$, I'll use the censored Tobit-regression. (ATS, 2008) This regression model shows which non-discretionary variable has significant effect on the performance of the higher education systems. In the case of the significant variables, sensitivity analysis provides the minimum magnitude of change required in variable values to reclassify a DMU. The absolute value of this sensitivity score doesn't give us useful information. More important is the comparison of the rates of each countries, because I'd like to answer which country reacts more sensitively to the changes of the environmental factors.

\section{Results and discussion}

In table 2 I report results for the standard DEA variablereturns-to scale efficiency scores and peers of each of the 19 considered countries.

It's easy to observe from table 2 that most efficient countries with the standard approach are Belgium, Denmark, Iceland, Italy, the Slovak Republic and Spain. Hungary is ranked to the 16 . place. If our country wants to become efficient, it will have to aim at the position of Iceland and the Slovak Republic - as peers. Greece, Poland and Turkey are located on the opposite end of the rank. Turkey is the only state with efficiency score under 0,9 , since the ratio of the population that has attained tertiary education is only $13 \%$,
Table 2: Results for higher education efficiency

\begin{tabular}{|l|c|c|l|}
\hline \multirow{2}{*}{ Countries } & \multicolumn{3}{|c|}{ OUTPUT-ORIENTED DEA } \\
\cline { 2 - 4 } & VRS & Rank & Peers \\
\hline Austria & 0,934 & 15 & Iceland \\
\hline Belgium & 1,000 & 1 & Belgium \\
\hline Czech Republic & 0,975 & 11 & Iceland, Slovak Republic \\
\hline Denmark & 1,000 & 1 & Denmark \\
\hline Finland & 0,964 & 12 & Denmark, Iceland \\
\hline France & 0,983 & 9 & Belgium, Denmark, Iceland \\
\hline Germany & 0,940 & 13 & Iceland, Slovak Republic \\
\hline Greece & 0,905 & 18 & Iceland \\
\hline Hungary & 0,913 & 16 & Iceland, Slovak Republic \\
\hline Iceland & 1,000 & 1 & Iceland \\
\hline Italy & 1,000 & 1 & Italy \\
\hline Netherlands & 0,976 & 10 & Belgium, Denmark, Iceland \\
\hline Poland & 0,908 & 17 & Iceland \\
\hline Portugal & 0,939 & 14 & Iceland \\
\hline Slovak Republic & 1,000 & 1 & Slovak Republic \\
\hline Spain & 1,000 & 1 & Spain \\
\hline Sweden & 0,990 & 8 & Belgium, Denmark, Iceland \\
\hline Turkey & 0,865 & 19 & Iceland, Slovak Republic \\
\hline United Kingdom & 0,998 & 7 & Belgium, Denmark, Iceland \\
\hline
\end{tabular}

Source: own calculations

and the employment rate of people with a diploma is almost $10 \%$ less, than the European average.

In order to analyse the effects of the environmental factors I create three models. The first model contains all the explanatory variables. Table 3 provides information on the parameter estimates and values of significance and $\mathrm{R}^{2}$.

Table 3: Censored normal Tobit results

\begin{tabular}{|l|c|c|c|}
\hline & Model 1 & Model 2 & Model 3 \\
\hline Constant & $\begin{array}{c}1.047293 \\
(<0.0001)\end{array}$ & $\begin{array}{c}1.060891 \\
(<0.0001)\end{array}$ & $\begin{array}{c}0.907923 \\
(<0.0001)\end{array}$ \\
\hline \multirow{2}{*}{ GDPP } & $\begin{array}{c}0.229 \mathrm{e}^{-5} \\
(0.0008)\end{array}$ & $\begin{array}{c}0.2536 \mathrm{e}^{-5} \\
(0.0003)\end{array}$ & $\begin{array}{c}0.2151 \mathrm{e}^{-5} \\
(0.0048)\end{array}$ \\
\hline \multirow{2}{*}{ PEA } & $\begin{array}{c}0.000506 \\
(0.2628)\end{array}$ & & \\
\hline \multirow{2}{*}{ PTT } & -0.002139 & -0.001993 & \\
\hline R $^{\mathbf{2}}$ & $(0.0257)$ & $(0.0500)$ & \\
\hline
\end{tabular}

Source: own calculations

The education level of the parents doesn't prove to be statistically significant, probably because European countries try to actively monitor and sustain the high equity of schooling. According to an OECD-study prepared in 2007 equity "implies ensuring that personal and social circumstances - for example gender, socio-economic status or ethnic origin - should not be an obstacle to achieving educational potential." (OECD, 2007) That's why in model 2 there are only two variable: GDP per capita and public-tototal expenditure ratio. If we accept the significance level of 0,05 , the estimated coefficients of both non-discretionary 
inputs are statistically significant. While higher GDP per capita results in more efficiency, public-to-total expenditure ratio is related negatively to the efficiency measure. For example, an increase of the state support of higher education sector reduces to the efficiency score. In other words, the higher private contribution to the expenditures of universities and colleges implies that the given country moves closer to the theoretical production possibility frontier. Since the GDP per capita has the most significant effect to the efficiency score, it worth studying what happens by dropping out both of the other explanatory factors. Despite of the fact that GDP per capita behaves significant in model 3 , model 2 is much better, because R2 is almost $20 \%$ higher - the variance of GDPP and PTT explains more than the half of the variance of DEA variable-returns-to-scale efficiency values.

The last operation of my study is analysing the sensitivity of the performance of higher education systems to the changes of the significant non-discretionary inputs separately. By calculating the minimum necessary magnitude of change in the variable values to the improvement of the state's position, I'm able to make a sensitivity ranking regarding to the explanatory factors. Figure 1 illustrates the rankings of the European higher education systems.

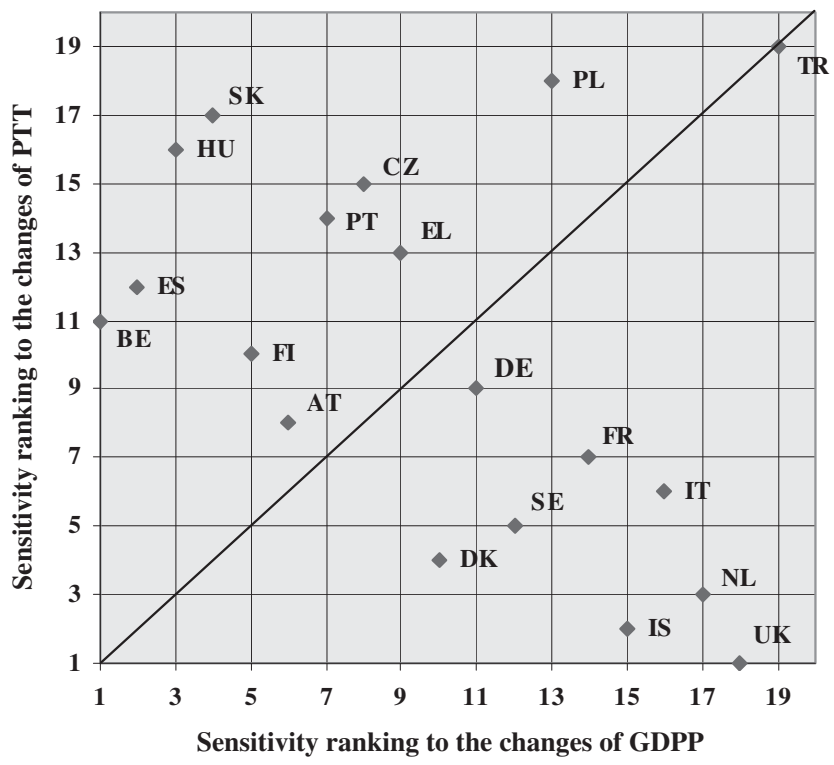

Figure 1: Sensitivity rankings of European higher education systems Source: own demonstration

In the case of the countries below and to the right of the diagonal the changes of GDP per capita induce most substantial shift of the efficiency measures than the changes of the state support of higher education. On the other hand, states above and to the left of the diagonal react more sensitively to the changes of PTT. By comparing the details of figure 1 to the value of GDPP and PTT it's possible to observe that the poorer countries are located above and to the left of the diagonal, while richer states with lower levels of state support are found on the opposite side of the figure. The last important conclusion is that the changes of GDP per capita are more significant at two thirds of the most efficient higher education systems, than the shift of PTT.

\section{Conclusion}

In my study, I aimed to determine the relationship between the efficiency of European higher educations systems and the degree of state support as well as the family's socio-economic background. I found that the GDP per capita has the most considerable influence on what results the countries achieve in higher education relative to their inputs, and the degree of the state contribution is negatively correlated to the efficiency measure. I can conclude that the rise of the private contribution to the expenses of higher education (for example by introducing tuition fees) is a more effective tool of the enhancement of efficiency in the poorer countries than in the richer ones.

\section{References}

Cooper, W. - Lawrence, M. S. - Tone, K. (2007): Data Envelopment Analysis - A Comprehensive Text with Models, Applications, References and DEA-Solver Software, Springer Science and Business Media, New York, 1-2. ISBN 0-387-45281-8

Friedman, M. (1996): Capitalism and freedom. Akadémiai Kiadó, Budapest, 94-117. ISBN 963-056-994-9

Hirschman, A. O. (1995): Exit, voice and loyalty. Osiris Kiadó, Budapest, 108-112. ISBN 963-3790-80-8

Kováts G. (2006): A felsőoktatási intézmények finanszírozási modelljei. Közgazdasági Szemle, LIII. 2006. október. 919-938. ISSN 1588-113X

Schultz, T. W. (1983): Investment in human capital. Közgazdasági és Jogi Könyvkiadó, Budapest, 60-61. ISBN 963221-250-9

Tibenszkyné Fórika K. (2007): Az oktatás hatékonyságának mérése a ZMNE 2006-ban végzett hallgatóin DEA módszer használatával. Hadmérnök, II. évf., 2. szám ISSN 1788-1919

ATS (2008): Stat computing - SAS - Data Analysis Examples - Tobit Analysis. University of California - Academic Technology Services. http://www.ats.ucla.edu/stat/sas/dae/tobit.htm

GVH (2007): Verseny és termelékenység. Budapest, 2007. június 12. http://www.gvh.hu

OECD (2007): No more failures: Ten steps to equity in education.

http://213.253.134.43/ oecd/pdfs/browseit/9107041E.PDF

OECD (2008): Education at a Glance - OECD indicators. Paris, http://www.sourceoecd.org

WRI (2006): Earthtrends - Environmental variables. World Resources Institute,

http://earthtrends.wri.org/text/economics-business/variable638.html 